\title{
Phytomining Applied for Postmining Sites
}

\section{Hermann Heilmeier}

\begin{abstract}
The economics associated with establishing and growing vegetation at contaminated sites can be improved if a metal that has commercial value can be extracted from the soil by plants. Phytomining is the process of extracting a product such as nickel from soil using hyperaccumulator plants that are able to grow in the contaminated soil and accumulate a metal product of value. After harvesting the plant biomass, drying it, and burning it for energy recovery, the ash can be processed to extract the metal of interest. Nickel and gold are good examples of products that have commercial value when phytomining is implemented at a contaminated site. Solar energy is used in phytomining, and soil quality is improved in many cases by increasing soil organic carbon and improving biological health and diversity in the soil. This chapter includes a review of phytomining and an analysis of its applications at contaminated sites containing metals that have commercial value.
\end{abstract}

\section{CONTENTS}

4.1 Introduction

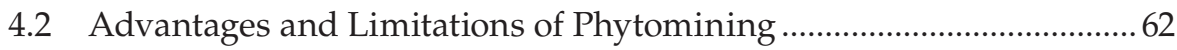

4.3 Field Experiments on Phytomining ...................................................6 64

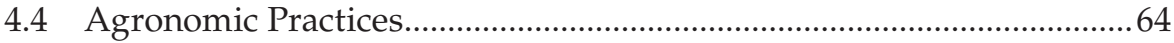

4.5 Economic Viability and Environmental Considerations .......................66

4.6 Options for Commercial Application of Phytomining ........................6 68

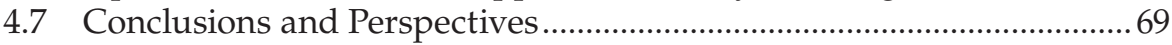

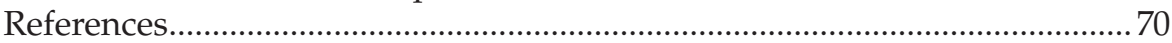

\subsection{Introduction}

Phytomining uses the capacity of plants and their associated microorganisms to extract and accumulate trace elements at high concentrations in their (above-)ground biomass (phytoextraction). However, in contrast to applications of phytoextraction for removing toxic trace elements (e.g., heavy metals, 
arsenic, selenium) from the environment as one option of phytoremediation (Pilon-Smits, 2005), the aim of phytomining processes is to extract commercially valuable elements from sources where the concentration of these elements is too low for economic activities applying conventional mining technologies, such as subeconomic ore bodies, mineral wastes (mine tailings), metal-bearing, or polluted soils, e.g., in (post-)mining areas (Heilmeier \& Wiche, 2020; Naila et al., 2019; Sheoran et al., 2009). Most prominent examples in phytomining applied "hyperaccumulator" plants, particularly for nickel (e.g., Anderson et al., 1998; Kidd et al., 2018; Li et al., 2003) or gold (e.g., Wilson-Corral et al., 2011). The term "hyperaccumulator" had been proposed by Brooks et al. (1977) for plant taxa that accumulate above $1000 \mathrm{mg}$ $\mathrm{kg}^{-1}$ of nickel (Ni) in their aboveground dry biomass. In the meantime, the term "hyperaccumulator" has been applied to a number of different elements, with respective adjustments of the concentration level (Jaffré et al., 2018; Rascio \& Navari-Izzo, 2011; Van der Ent et al., 2013). Hyperaccumulator plant species were first suggested by Chaney (1983) for the purpose of phytomining. Nicks \& Chambers $(1995,1998)$ were the first to perform field trials on phytomining of $\mathrm{Ni}$, using the naturally occurring Ni-hyperaccumulator Streptanthus polygaloides. Brooks et al. (1998) argued that phytomining of Ni should be generally feasible due to a number of plants which accumulate $\mathrm{Ni}$ to high shoot concentrations $\left(>10,000 \mathrm{mg} \mathrm{kg}^{-1}\right)$ and produce high biomass $\left(>10 \mathrm{t} \mathrm{ha}^{-1}\right)$. Soon, other elements such as thallium, copper, cobalt, and particularly gold have been tested for their phytomining potential (Anderson et al., 1998; Sheoran et al., 2013; Wilson-Corral et al., 2011, 2012).

In this chapter advantages and limitations of phytomining will be discussed, followed by a description of field experiments, particularly for phytomining of gold and $\mathrm{Ni}$ applying the so-called "hyperaccumulator plants" and recommendation for agronomic practices as derived from these experiments. Problems of economic viability and environmental implications will be addressed, based on the outcomes of various modelling studies. Examples on options of commercial application include phytomining for Ni from ultramafic soils, production of nanoparticles as catalysts, and extraction of valuable elements such as rare earth elements (REEs) from secondary sources for raw materials such as mine tailings.

\subsection{Advantages and Limitations of Phytomining}

In comparison to conventional mining technologies phytomining has several advantages. The two most important advantages are the fact that phytomining offers the option to exploit ores that are not economic for conventional mining approaches (Anderson et al., 1999), and the low cost of operation (Robinson et al., 2003). Further advantages are the use of 
cheap solar energy for creating a "bio-ore", low energy inputs for melting, less $\mathrm{SO}_{x}$ emissions due to bio-ore being sulfur-free, the improvement of site quality and other synergy effects with related industries as a consequence of biomass growth, e.g., generation of bioenergy (combustion, fermentation, generation of heat and biofuels), and the public acceptance as a "green" technology (Ali et al., 2013; Harris et al., 2009; Koptsik, 2014; Robinson et al., 2003; Saxena et al., 2020). With respect to the environment the sequestration of atmospheric carbon dioxide $\left(\mathrm{CO}_{2}\right)$ in plant biomass and due to enrichment of soils with organic matter and other ecosystem effects such as increased soil biodiversity, improved agronomic crop productivity, land restoration and pollution control are of relevance, which have to be considered in complete economic analyses (Kidd et al., 2018; Saxena et al., 2020). Thus, already around the turn of the century, Li et al. (2003) pointed to the option of sales of carbon credits. Robinson et al. (2009) emphasized the positive effects of phytomining in the remediation of sites polluted and degraded, e.g., due to mining and metallurgical processes, tailings, dumps, etc. The reduction of erosion (wind, surface runoff) and leaching of toxic substances to groundwater will improve water quality (Saxena et al., 2020). In summary, phytoremediation is "safe, aesthetic, nonaggressive, nondestructive" (Koptsik, 2014).

However, there are also severe limitations and restrictions negatively affecting the general applicability and success of phytomining. The most important limitation is due to the plants' shallow rooting system which allows for minerals close to the surface only to be extracted via this "green" technology (Hunt et al., 2014; Robinson et al., 2003). Furthermore, adverse site conditions, e.g., poor physical and chemical properties of soils on contaminated sites, usually limit plant growth severely; most stressful soil factors are the low content of nutrients and soil organic matter, and high soil acidity leading to solution of heavy metals (Hunt et al., 2014; Koptsik, 2014). Koptsik (2014) and Saxena et al. (2020) point out that for climatic and seasonal reasons, phytomining is more suitable in tropical and subtropical climates. Robinson et al. $(2003,2009)$ emphasize that phytomining is a long-term process with a much larger demand for area per unit of valuable elements compared to conventional mining and therefore may cause huge environmental disturbances in case, e.g., of clearing of natural vegetation for phytomining. Even if the total concentration of target elements in the soil may be high, their availability to the plants is often too low for effective uptake (Heilmeier \& Wiche, 2020; Robinson et al., 2009; Sheoran et al., 2009). Hyperaccumulators with high uptake rates often show a low biomass production (Hunt et al., 2014; Robinson et al., 2003). Thus, two options for increasing element uptake of nonaccumulator plants have been proposed: (i) genetically modified plants (e.g., Hunt et al., 2014; Koptsik, 2014; Saxena et al., 2020); (ii) "induced hyperaccumulation" via applying chelating soil amendments (e.g., Hunt et al., 2014; Koptsik, 2014; Robinson et al., 2003; Wang et al., 2020; Wilson-Corral et al., 2012). 


\subsection{Field Experiments on Phytomining}

Whereas part of the initial experiments on phytomining had been conducted under totally artificial conditions in the laboratory, applying, e.g., solubilizing agents such as ammonium thiocyanate for phytoextraction of gold (e.g., Anderson et al., 1998), systematic field trials, following the pioneering work of Nicks \& Chambers $(1995,1998)$ and Robinson et al. $(1997 a, b)$ on Ni, have been performed by Anderson et al. (2005) for gold (Au), testing the two plant species Brassica juncea (Indian mustard) and Zea mays (corn), commonly used for phytoremediation and as energy crops. Applying an empirical model on the relationship between Au concentration in the soil and in plants obtained from laboratory and greenhouse studies, they suggested a minimum Au concentration in the substrate of $2 \mathrm{mg} \mathrm{kg}^{-1}$ to achieve a gold concentration in crops of $100 \mathrm{mg} \mathrm{kg}^{-1}$, which, given a biomass harvest of $10 \mathrm{t} \mathrm{ha}^{-1}$, would yield an economically viable gold recovery of $1 \mathrm{~kg}$ in plants per hectare. The authors proposed reclamation of spent heap-leach piles or retreatment of waste dumps, e.g., from artisanal gold mining as possible applications. Later on, Wilson-Corral et al. (2011), by application of chemical amendments, achieved average Au concentrations in leaves and stems of Helianthus annuus (sunflower) up to 19 and $21 \mathrm{mg} \mathrm{kg}^{-1}$, still being well below the economic threshold proposed by Anderson et al. (2005). A field experiment to assess phytomining feasibility for artisanal gold mining tailings with tobacco plants, applying $\mathrm{NaCN}$ as chelating agent, however yielded Au concentrations of $1.2 \mathrm{mg} \mathrm{kg}^{-1}$ dry leaf biomass only (Krisnayanti et al., 2016).

The most promising element for phytomining at present is Ni (Kidd et al., 2018; Nkrumah et al., 2016). In a large number of experiments some ten plant species, with a focus on Alyssum murale (syn. Odontarrhena chalcidica) (e.g., Matko Stamenković et al., 2017; Rosenkranz et al., 2019), have been tested for their phytomining potential on ultramafic or Ni contaminated soils in different parts of the world. A major outcome from these studies is the positive effect of fertilization with nitrogen $(\mathrm{N})$, phosphorus $(\mathrm{P})$, and potassium $(\mathrm{K})$ and of addition of organic matter on biomass of Ni hyperaccumulating plants, and the increase of $\mathrm{Ni}$ uptake and accumulation in shoots by adjustment of soil $\mathrm{pH}$ (optimum pH 5-7), addition of sulfur (S), or inoculation with (rhizo-)bacteria and mycorrhiza (Kidd et al., 2018; Nkrumah et al., 2016; Rosenkranz et al., 2019).

\subsection{Agronomic Practices}

As shown above for gold, the application of synthetic solubilizing agents greatly enhances Au uptake and accumulation in the aboveground biomass (Anderson et al., 1998; González-Valdez et al., 2018; Wilson-Corral et al., 2011). However, apart from the high costs of chelators, chemically induced hyperaccumulation, 
as already pointed out by Robinson et al. (2003), bears a number of serious environmental risks, such as persistence time of the chelators in the environment, leaching of mobilized toxic trace elements to ground water, or toxicity to plants and their associated microbes being used for phytomining (Hunt et al., 2014; Robinson et al., 2009; Saxena et al., 2020; Wang et al., 2020; Wilson-Corral et al., 2011). For that reason, more "natural" approaches such as soil management via conventional agricultural technologies have been initiated already among the first field trials, e.g., management of $\mathrm{pH}$ and fertilization (both inorganic, e.g., NPK, and organic, e.g., composted sewage sludge) for enhancing plant growth and phytoaccumulation of $\mathrm{Ni}$ (Chaney et al., 2007; Kidd et al., 2018; Li et al., 2003). Later on, co-cropping has been adopted for enhancing phytoextraction (Tang et al., 2012). Due to the low availability of target elements often limiting phytomining success (Heilmeier \& Wiche, 2020; Sheoran et al., 2009), the stimulation of biological activity in the soil, particularly the rhizosphere, seems to be a most promising approach (Robinson et al., 2009). Apart from enhancing biomass production by Plant Growth Promoting Rhizobacteria, the exudation of metabolites such as organic acids and metal-chelating siderophores by soil microorganisms may change speciation of trace elements and thus greatly increase their solubility and bioavailability in the rhizosphere (Kidd et al., 2018; Koptsik, 2014; Saxena et al., 2020; Wiche et al., 2017).

Plant-targeted approaches include both traditional breeding for combining agronomic traits relevant for successful phytoaccumulation (Hunt et al., 2014; Li et al., 2003; Nkrumah et al., 2016; Robinson et al., 2009) or genetic approaches (Koptsik, 2014; Li et al., 2003), particularly for metal transporters (Hunt et al., 2014; Robinson et al., 2009). The most important criteria when selecting plant species for phytomining are as follows (Hunt et al., 2014; Koptsik, 2014; Li et al., 2003; Nkrumah et al., 2016; Saxena et al., 2020):

- easy cultivation as an agricultural crop, e.g., high rates of germination and establishment, easy propagation via seeds or cuttings

- adaptation to site climatic and edaphic conditions

- resistance to diseases and pests

- rapid growth

- high biomass yield

- extensive root system (deep, highly branched)

- high tolerance of elevated concentrations of (toxic) trace elements and extreme soil properties ( $\mathrm{pH}$, salinity)

- high specificity for target element(s)

- high uptake and translocation of target element(s) from roots to shoot

- high accumulation potential for target element(s) in aboveground plant parts

- potential for use as energy crop (burning, fermentation) 
No single plant species will show all these traits; however, collection of germplasm from a diversity of accumulator plant species, testing potentials for agronomic yield and element accumulation on a variety of substrates with various soil management, and either conventional breeding or genetic manipulation should contribute to generate optimum "phytominers".

In conclusion, from an agroecosystem point of view, a combination of the following practices is the most promising approach (Kidd et al., 2018; Li et al., 2003; Nkrumah et al., 2016; Robinson et al., 2009; Tang et al., 2012; Wang et al., 2020):

- soil management

- soil amendments (regulation of $\mathrm{pH}$, inorganic, and organic fertilizers)

- ploughing $\rightarrow$ decrease of soil heterogeneity (patchiness of concentration of target elements); translocation of target elements from deeper soil horizons close to soil surface

- crop management

- planting: seeding depth, seed bed preparation, germination requirements, direct seeding, seed pelletization, transplanting

- planting density (dependent on soil physical properties, organic matter and nutrient levels, plant species)

- plant life form (annual, perennial)

- co-cropping/intercropping $\rightarrow$ affects conditions in the rhizosphere $\rightarrow$ increased bioavailability of target element(s)

- weed control

- harvest methods: machinery for aboveground biomass, time of harvesting (effect on element and bioenergy yield); double harvesting

- plant breeding

Widening the scope from the earlier focus on (hyper-)accumulators to the whole soil-plant agrosystem has been mirrored in the term "agromining" (Nkrumah et al., 2018). "Metal crops", i.e., plant species accumulating heavy metals, precious elements, or REEs, with a high biomass yield, have now become the focus of research (Li et al., 2020).

\subsection{Economic Viability and Environmental Considerations}

The agro-ecological expenditures related to plant cultivation as discussed above are only part of the costs of a complete phytomining approach, which also include processing of the plant biomass for recovery of the economically 
valuable elements. First crude economic analyses of phytomining, based on chelate-induced phytoextraction for increasing the solubility of, e.g., gold $(\mathrm{Au})$, considered the costs for synthetic ligands added to the soil only (Anderson et al., 1998). Later on, more advanced economic models, including specified costs for site preparation, seeding, plant cultivation, application of fertilizers and chelating agents, and harvesting, yielded that expenditures for gold recovery by solvent extraction are the most dominant costs, which, however, can be dramatically reduced by burning biomass, thus reducing the volume of material for solvent extraction (Anderson et al., 2003). Burning of dry plants (e.g., Odontarrhena muralis with $1 \% \mathrm{Ni}$ in the plant mass) yielded a concentration factor for $\mathrm{Ni}$ of ca. 12 (Kidd et al., 2018). Thus, depending on the initial plant concentration of $\mathrm{Ni}(1 \%-2 \%$ in several hyperaccumulators of the Brassicaceae family), Ni concentration in the ash may reach values of $10 \%-20 \%$ which is much more than in Ni ore mined from laterites (Simonnot et al., 2018). Robinson et al. (2003) developed a detailed mathematical model for assessing economic viability of phytomining as a function of multiple variables (costs for planting and producing biomass, value of biomass, and bio-ore) including interest rates and compared phytoextraction with alternative technologies. Applying their model to phytomining of $\mathrm{Ni}$ and $\mathrm{Au}$ in Australia, Harris et al. (2009) concluded that the most decisive factors for profitability are metal prices and the content of extractable metal(s). Another application of the same model by Wilson-Corral et al. (2012) concluded that phytomining for Au should be economically lucrative for metalliferous or abandoned mine sites. For less precious metals than gold, such as Ni, Van der Ent et al. (2015) emphasized the added market value of Ni catalysts for organic chemistry or pure Ni salt crystals.

An important issue neglected in early cost-benefit analyses is related to generation of bioenergy, e.g., via fermentation or combustion, and to increase of soil organic matter and sequestration of atmospheric $\mathrm{CO}_{2}$ particularly on infertile marginal soils, the sale of carbon dioxide credits as already pointed out by Li et al. (2003). Carbon credits are part of a more holistic environmental evaluation of phytomining as proposed by Van der Ent et al. (2015). Kidd et al. (2018) advocated Life Cycle Assessment (LCA) as the most recognized method with many applications in agriculture and phytoremediation (see literature cited in Kidd et al., 2018). One of the first applications of LCA in the framework of phytomining was performed by Rodrigues et al. (2016), who considered, among others, toxicity to humans and environmental pollution caused by soil erosion (e.g., eutrophication) as a consequence of nonconservative agriculture. Erosion control, e.g., by contour farming or winter cover crops, can reduce not only loss of valuable metals but also impairment of human and ecosystem health. In addition, the use of biomass of accumulator plants not only reduces costs of phytomining but avoids atmospheric $\mathrm{CO}_{2}$ increase by substituting fossil fuels. Already 1 year earlier, Echevarria et al. (2015) had emphasized a number of ecosystem services such as amelioration of soil quality, production of biofuel, conservation and restoration of biodiversity (protection of rare 
and endangered species, support of pollinating insects), and enhancement of carbon storage in soils. Apart from these positive ecological and environmental effects, Kidd et al. (2018) critically discuss also possible negative effects of phytomining on biodiversity (introduction of exotic species, behavioral consequences for pollinators by metal contents of flowers), soil $\mathrm{CO}_{2}$ emissions as dependent on agricultural management, depletion of natural resources (e.g., water in case of irrigation), and the natural environment (land use and land use change), and emphasize the need for more research on descriptors and indicators, assessment methods, and cause-and-effect chain models on ecosystem services (Bouma \& van Beukering, 2015; Kumar, 2010).

\subsection{Options for Commercial Application of Phytomining}

Although phytomining has a number of technological, economic, and environmental advantages, among others due to limitations as discussed in Section 4.2 (limited soil volume explored by plant rooting systems, adverse site conditions, low bioavailability of target elements), there is limited experience with field experiments (see Section 4.3) and technological applications. The most well-known and popular application of phytoremediation is the use of Alyssum murale for extracting Ni from ultramafic soils at the shores of Lake Ohrid in Albania, e.g., by the French company Econick (2018), based on long-term research on improving phytomining efficiency, e.g., by fertilization, weed control, and planting techniques (Bani et al., 2015). Ni recovered by hyperaccumulator plants can be processed, e.g., via hydrometallurgical technologies which have already been developed up to pilot scale for the production of Ni salts (ammonium and nickel sulfate hexahydrate, nickel sulfate, nickel acetate, etc. (Simonnot et al., 2016).

Already 10 years earlier, Haverkamp et al. (2007) suggested to synthesize metal nanoparticles by plants for catalytic purposes. Harumain et al. (2017) tested the suitability of plant species from various growth forms (mustard, miscanthus, willow) to extract palladium (Pd) from mine-sourced tailings. Although the accumulation of Pd was still below the target for commercially available 3\% Pd-on-carbon catalysts, authors emphasize the strong potential for supplementary Pd supply by phytomining and positive environmental effects due to re-vegetation of tailings and other areas contaminated by mining activities and the restoration of their ecosystem functions.

The potential of both woody (e.g., Populus tremula) and nonwoody (e.g., Phragmites australis and Phalaris arundinacea) plant species for extracting valuable elements such as germanium and REEs from a dump field has also been demonstrated by Midula et al. (2017). An alternative source for conservation of primary resources by phytoextraction was suggested by Rosenkranz et al. (2017): waste incineration bottom ash. "Exotic" elements investigated so far 
were studied by Novo et al. (2015) for phytomining potential of Rhenium with Indian mustard (expected profit ca. 4000 US- $\$ \mathrm{ha}^{-1}$ ) and Shi et al. (2020) for platinum group metals to obtain nanoparticles, both under controlled conditions.

One of the earliest extended field experiments on phytoremediation of a former Uranium mining site (plot size $2 \mathrm{~m} \times 2 \mathrm{~m}, 1 \mathrm{~m}$ deep) was performed by Willscher et al. (2013) at Ronneburg (Thuringia, Germany). Soil improvement (amendment with calcareous top soil, mycorrhiza+bacteria) reduced the concentration of contaminants in seepage water, and rates and loads of seepage water. Neither ethanol fermentation nor biogas production was inhibited by uranium or heavy metals accumulated in low concentrations in the plant biomass; thus, the plant material from phytoremediation could be used for winning of bioenergy.

Another large-scale experiment for remediation of polluted soils via phytotechnologies has been carried out in Southwestern Europe (PhytoSUDOE, 2019). Nonfood crops, supported by soil amendments such as compost and bioaugmentation (inoculation with beneficial microorganisms), have been cultivated for rehabilitation of contaminated sites and production of useable biomass in Portugal, Spain, and France.

As shown by Harumain et al. (2017) and Midula et al. (2017), mine tailings are a huge reservoir of secondary resources, not only of elements considered traditionally in phytomining such as gold and nickel but also of less common elements such as palladium (Pd), germanium (Ge), and REEs. The phytomining potential for Ge and REEs has been investigated for a number of herbaceous plant species (both forbs and grasses) at experimental field sites close to Freiberg (Saxony, Germany), with the option to generate bioenergy either via fermentation or combustion. Whereas grasses such as $P h$. arundinacea, Avena sativa, or Zea mays proved to be good accumulators for Ge due to their high capacity for uptake of the chemically similar Silicium, forbs like Fagopyrum esculentum or Brassica napus turned out to accumulate high amounts of REEs (Wiche \& Heilmeier, 2016). Intercropping of $A$. sativa (oat) with Lupinus albus (white lupine), a leguminous plant with a high capacity for exudation of organic acids (e.g., citric acid) which can increase bioavailability of elements in the soil, increased accumulation of REEs in oat (Wiche et al., 2016). According to an economic analysis by Rentsch et al. (2016), both the accumulation of target elements in the plants and the high costs of extraction of target elements from fly ash after combustion of fermentation residues from biogas production are key factors for economic feasibility.

\subsection{Conclusions and Perspectives}

Although there are still major challenges to be passed for an economically viable application of phytomining on a broad scale, such as selection and improvement of promising target plants and the low bioavailability of target elements 
in the rooting environment, there are already some successful approaches, particularly for the element $\mathrm{Ni}$, applying naturally occurring hyperaccumulator plants on ultramafic soils. Bio-ores produced via phytomining have a number of advantages compared to mineral ores, such as low energy demand for melting and less emissions of sulfur dioxide. Furthermore, plants have the capacity to synthesize nanoparticles with a high catalytic and absorptive activity. Nevertheless, optimizing processing of bio-ores for recovery of target elements and an improved understanding of plant-microbe-element interactions and stimulation of rhizosphere processes (e.g., via co-cropping) to increase bioavailability and thus accumulation of target elements in plants will be key parameters for economic viability of phytomining at the individual business company level. Economic return can be increased by utilizing bioenergy (fermentation, combustion) from accumulator plants; however, this requires more breeding efforts considering the low biomass yield of most (hyper)accumulator plants. Returning fermentation residues from biogas production as fertilizers to field sites will not only increase biomass yield of accumulator plants via fertilizing effects but also close nutrient loops (circular economy). Furthermore, application of organic matter from fermentation residues on marginal sites will improve soil conditions, reduce soil erosion, and thus contribute to soil and (ground-)water protection. In addition, sequestration of atmospheric $\mathrm{CO}_{2}$ due to long-term soil improvement allows sales of carbon dioxide credits, which will not only increase financial returns on a microeconomic level but should also be included as positive effects of phytomining at the macroeconomic level as part of a more holistic economic and ecological evaluation of mining.

\section{References}

Ali, H., Khan, E., \& Sajad, M. A. (2013). Phytoremediation of heavy metals-Concepts and applications. Chemosphere, 91(7), 869-881. https://doi.org/10.1016/j. chemosphere.2013.01.075.

Anderson, C. W. N., Brooks, R. R., Chiarucci, A., Lacoste, C. J., Leblanc, M., Robinson, B. H., Simcock, R., \& Stewart, R. B. (1999). Phytomining for nickel, thallium and gold. Journal of Geochemical Exploration, 67(1-3), 407-415. https://doi.org/10.1016/ S0375-6742(99)00055-2.

Anderson, C. W., Brooks, R. R., Stewart, R. B., \& Simcock, R. (1998). Harvesting a crop of gold in plants. Nature, 395(6702), 553-554. https://doi.org/10.1038/26875.

Anderson, C., Moreno, F., \& Meech, J. (2005). A field demonstration of gold phytoextraction technology. Minerals Engineering, 18(4), 385-392. https://doi. org/10.1016/j.mineng.2004.07.002.

Anderson, C. W. N., Stewart, R. B., Moreno, F. N., Wreesmann, C. T. J., GardeaTorresdey, J. L., Robinson, B. H., \& Meech, J. A. (2003). Gold phytomining. Novel developments in a plant-based mining system. Proceedings of the Gold 2003 Conference: New Industrial Applications of Gold. 
Bani, A., Echevarria, G., Sulçe, S., \& Morel, J. L. (2015). Improving the agronomy of Alyssum murale for extensive phytomining: A five-year field study. International Journal of Phytoremediation, 17(2), 117-127. https://doi.org/10.1080/15226514.2013.862204.

Bouma, J. A., \& van Beukering, P. J. H. (2015). Ecosystem Services: From Concept to Practice. Cambridge University Press, Cambridge, UK. ISBN: 9781107062887.

Brooks, R. R., Lee, J., Reeves, R. D., \& Jaffre, T. (1977). Detection of nickeliferous rocks by analysis of herbarium specimens of indicator plants. Journal of Geochemical Exploration, 7(C), 49-57. https://doi.org/10.1016/0375-6742(77)90074-7.

Brooks, R. R., Chambers, M. F., Nicks, L. J., \& Robinson, B. H. (1998). Phytomining. Trends in Plant Science, 3(9), 359-362. https://doi.org/10.1016/S1360-1385(98)01283-7.

Chaney, R. L. (1983). Plant uptake of inorganic waste. In: Parr, J. F., Marsh, P. B., Kla, J. M. eds. Land Treatment of Hazardous Wastes, 50-76. Noyes Data Corporation, Park Ridge, NJ. ISBN: 10: 081550926X.

Chaney, R. L., Angle, J. S., Broadhurst, C. L., Peters, C. A., Tappero, R. V., \& Sparks, D. L. (2007). Improved understanding of hyperaccumulation yields commercial phytoextraction and phytomining technologies. Journal of Environmental Quality, 36(5), 1429-1443. https://doi.org/10.2134/jeq2006.0514.

Echevarria, G., Baker, A., Morel, J.-L., Van Der Ent, A., Houzelot, V., Laubie, B., Pons, M.-N., Simonnot, M.-O., Zhang, X., Kidd, P., Benizri, E., Louis, J., Pons, M.-N., \& Bani, A. (2015). Agromining for nickel: A complete chain that optimizes ecosystem services rendered by ultramafic landscapes. 13th SGA Meeting "Mineral Resources in a Sustainable World, Society for Geology Applied to Mineral Deposits (SGA). DEU. ASGA Association Scientifique Géologie \& Applications. https:// hal.archives-ouvertes.fr/hal-01263575.

Econick. (2018). https://www.econick.fr/fr (last accessed October 29, 2020).

González-Valdez, E., Alarcón, A., Ferrera-Cerrato, R., Vega-Carrillo, H. R., MaldonadoVega, M., Salas-Luévano, M. Á., \& Argumedo-Delira, R. (2018). Induced accumulation of $\mathrm{Au}, \mathrm{Ag}$ and $\mathrm{Cu}$ in Brassica napus grown in a mine tailings with the inoculation of Aspergillus niger and the application of two chemical compounds. Ecotoxicology and Environmental Safety, 154, 180-186. https://doi.org/10.1016/j. ecoenv.2018.02.055.

Harris, A. T., Naidoo, K., Nokes, J., Walker, T., \& Orton, F. (2009). Indicative assessment of the feasibility of $\mathrm{Ni}$ and Au phytomining in Australia. Journal of Cleaner Production, 17(2), 194-200. https://doi.org/10.1016/j.jclepro.2008.04.011.

Harumain, Z. A. S., Parker, H. L., Muñoz García, A., Austin, M. J., McElroy, C. R., Hunt, A. J., Clark, J. H., Meech, J. A., Anderson, C. W. N., Ciacci, L., Graedel, T. E., Bruce, N. C., \& Rylott, E. L. (2017). Toward financially viable phytoextraction and production of plant-based palladium catalysts. Environmental Science and Technology, 51(5), 2992-3000. https://doi.org/10.1021/acs.est.6b04821.

Haverkamp, R. G., Marshall, A. T., \& Van Agterveld, D. (2007). Pick your carats: Nanoparticles of gold-silver-copper alloy produced in vivo. Journal of Nanoparticle Research, 9(4), 697-700. https://doi.org/10.1007/s11051-006-9198-y.

Heilmeier, H., \& Wiche, O. (2020). The PCA of phytomining: principles, challenges and achievements. Carpathian Journal of Earth and Environmental Sciences, 15, 37-42. https://doi.org/10.26471/cjees/2020/015/106.

Hunt, A. J., Anderson, C. W. N., Bruce, N., García, A. M., Graedel, T. E., Hodson, M., Meech, J. A., Nassar, N. T., Parker, H. L., Rylott, E. L., Sotiriou, K., Zhang, Q., \& Clark, J. H. (2014). Phytoextraction as a tool for green chemistry. Green Processing and Synthesis, 3(1), 3-22. https://doi.org/10.1515/gps-2013-0103. 
Jaffré, T., Reeves, R. D., Baker, A. J. M., Schat, H., \& Van Der Ent, A. (2018). The discovery of nickel hyperaccumulation in the New Caledonian tree Pycnandra acuminata 40 years on: an introduction to a Virtual Issue. New Phytologist, 218, 397-400. https://doi.org/10.1111/nph.15105.

Kidd, P. S., Bani, A., Benizri, E., Gonnelli, C., Hazotte, C., Kisser, J., Konstantinou, M., Kuppens, T., Kyrkas, D., Laubie, B., Malina, R., Morel, J. L., Olcay, H., Pardo, T., Pons, M. N., Prieto-Fernández, Á., Puschenreiter, M., Quintela-Sabarís, C., Ridard, C., \& Echevarria, G. (2018). Developing sustainable agromining systems in agricultural ultramafic soils for nickel recovery. Frontiers in Environmental Science, 6(June), 44. https://doi.org/10.3389/fenvs.2018.00044.

Koptsik, G. N. (2014). Problems and prospects concerning the phytoremediation of heavy metal polluted soils: A review. Eurasian Soil Science, 47(9), 923-939. https://doi.org/10.1134/S1064229314090075.

Krisnayanti, B., Anderson, C., Sukartono, S., Afandi, Y., Suheri, H., \& Ekawanti, A. (2016). Phytomining for artisanal gold mine tailings management. Minerals, 6(3), 84. https://doi.org/10.3390/min6030084.

Kumar, P. (2010). The Economics of Ecosystems and Biodiversity: Ecological and Economic Foundations. UNEP/Earthprint, London. ISBN: 9781849712125.

Li, C., Ji, X., \& Luo, X. (2020). Visualizing hotspots and future trends in phytomining research through scientometrics. Sustainability, 12(11), 4593. https://doi. org/10.3390/su12114593.

Li, Y. M., Chaney, R., Brewer, E., Roseberg, R., Angle, J. S., Baker, A., Reeves, R., \& Nelkin, J. (2003). Development of a technology for commercial phytoextraction of nickel: Economic and technical considerations. Plant and Soil, 249(1), 107-115. https://doi.org/10.1023/A:1022527330401.

Matko Stamenković, U., Andrejić, G., Mihailović, N., \& Šinžar-Sekulić, J. (2017). Hyperaccumulation of $\mathrm{Ni}$ by Alyssum murale Waldst. \& Kit. from ultramafics in Bosnia and Herzegovina. Applied Ecology and Environmental Research, 15(3), 359-372. https://doi.org/10.15666/aeer/1503_359372.

Midula, P., Wiche, O., Wiese, P., \& Andráš, P. (2017). Concentration and bioavailability of toxic trace elements, germanium, and rare earth elements in contaminated areas of the Davidschacht dump-field in Freiberg (Saxony). Freiberg Ecology Online, 2, 101-112.

Naila, A., Meerdink, G., Jayasena, V., Sulaiman, A. Z., Ajit, A. B., \& Berta, G. (2019). A review on global metal accumulators-Mechanism, enhancement, commercial application, and research trend. Environmental Science and Pollution Research, 26, 26449-26471. https://doi.org/10.1007/s11356-019-05992-4.

Nicks, L. J., \& Chambers, M. F. (1995). Farming for metals. Mining Environmental Management, 3(3), 15-16.

Nicks, L. J., \& Chambers, M. F. (1998). Pioneering study of the potential of phytomining for nickel. In: Brooks, R. R. ed. Plants that Hyperaccumulate Heavy Metals: Their Role in Phytoremediation, Microbiology, Archaeology, Mineral Exploration and Phytomining, 313-325. CAB International, Wallingford. ISBN: 9780851992365.

Nkrumah, P. N., Baker, A. J. M., Chaney, R. L., Erskine, P. D., Echevarria, G., Morel, J. L., \& van der Ent, A. (2016). Current status and challenges in developing nickel phytomining: an agronomic perspective. Plant and Soil, 406(1-2), 55-69. https:// doi.org/10.1007/s11104-016-2859-4. 
Nkrumah, P. N., Chaney, R. L., \& Morel, J. L. (2018). Agronomy of 'metal crops' used in agromining. In: Van der Ent, A., Echevarria, G., Baker, A. J. M., Morel, J. L. eds. Agromining: Farming for Metals, 19-38. Springer, Cham. https://doi. org/10.1007/978-3-319-61899-9_2.

Novo, L. A. B., Mahler, C. F., \& González, L. (2015). Plants to harvest rhenium: Scientific and economic viability. Environmental Chemistry Letters, 13(4), 439-445. https:// doi.org/10.1007/s10311-015-0517-3.

PhytoSUDOE. (2019). http://www.phytosudoe.eu/en/ (last accessed October 29, 2020).

Pilon-Smits, E. (2005). Phytoremediation. Annual Review of Plant Biology, 56(1), 15-39. https://doi.org/10.1146/annurev.arplant.56.032604.144214.

Rascio, N., \& Navari-Izzo, F. (2011). Heavy metal hyperaccumulating plants: How and why do they do it? And what makes them so interesting? Plant Science, 180(2), 169-181. https://doi.org/10.1016/j.plantsci.2010.08.016.

Rentsch, L., Aubel, I. A., Schreiter, N., Höck, M., \& Bertau, M. (2016). PhytoGerm: Extraction of germanium from biomass - An economic pre-feasibility study. Journal of Business Chemistry, 13(1), 47-58.

Robinson, B., Fernández, J. E., Madejón, P., Marañón, T., Murillo, J. M., Green, S., \& Clothier, B. (2003). Phytoextraction: An assessment of biogeochemical and economic viability. Plant and Soil, 249(1), 117-125. https://doi. org/10.1023/A:1022586524971.

Robinson, B. H., Brooks, R. R., Howes, A. W., Kirkman, J. H., \& Gregg, P. E. H. (1997a). The potential of the high-biomass nickel hyperaccumulator Berkheya coddii for phytoremediation and phytomining. Journal of Geochemical Exploration, 60(2), 115-126. https://doi.org/10.1016/S0375-6742(97)00036-8.

Robinson, B. H., Chiarucci, A., Brooks, R. R., Petit, D., Kirkman, J. H., Gregg, P. E. H., \& De Dominicis, V. (1997b). The nickel hyperaccumulator plant Alyssum bertolonii as a potential agent for phytoremediation and phytomining of nickel. Journal of Geochemical Exploration, 59(2), 75-86. https://doi.org/10.1016/ S0375-6742(97)00010-1.

Robinson, B. H., Bañuelos, G., Conesa, H. M., Evangelou, M. W. H., \& Schulin, R. (2009). The phytomanagement of trace elements in soil. Critical Reviews in Plant Sciences, 28(4), 240-266. https://doi.org/10.1080/07352680903035424.

Rodrigues, J., Houzelot, V., Ferrari, F., Echevarria, G., Laubie, B., Morel, J. L., Simonnot, M. O., \& Pons, M. N. (2016). Life cycle assessment of agromining chain highlights role of erosion control and bioenergy. Journal of Cleaner Production, 139, 770-778. https://doi.org/10.1016/j.jclepro.2016.08.110.

Rosenkranz, T., Hipfinger, C., Ridard, C., \& Puschenreiter, M. (2019). A nickel phytomining field trial using Odontarrhena chalcidica and Noccaea goesingensis on an Austrian serpentine soil. Journal of Environmental Management, 242, 522-528. https://doi.org/10.1016/j.jenvman.2019.04.073.

Rosenkranz, T., Kisser, J., Wenzel, W. W., \& Puschenreiter, M. (2017). Waste or substrate for metal hyperaccumulating plants - The potential of phytomining on waste incineration bottom ash. Science of the Total Environment, 575, 910-918. https://doi.org/10.1016/j.scitotenv.2016.09.144.

Saxena, G., Purchase, D., Mulla, S. I., Saratale, G. D., \& Bharagava, R. N. (2020). Phytoremediation of heavymetal-contaminated sites:Eco-environmentalconcerns, field studies, sustainability issues, and future prospects. Reviews of Environmental Contamination and Toxicology, 249,71-131. https://doi.org/10.1007/398_2019_24. 
Sheoran, V., Sheoran, A. S., \& Poonia, P. (2009). Phytomining: A review. Minerals Engineering, 22(12), 1007-1019. https://doi.org/10.1016/j.mineng.2009.04.001.

Sheoran, V., Sheoran, A. S., \& Poonia, P. (2013). Phytomining of gold: A review. Journal of Geochemical Exploration, 128, 42-50. https://doi.org/10.1016/j. gexplo.2013.01.008.

Shi, P., Veiga, M., \& Anderson, C. (2020). Geochemical assessment of platinum group metals for phytomining. Revista Escola de Minas, 73(1), 85-91. https://doi. org/10.1590/0370-44672019730038.

Simonnot, M. O., Laubie, B., Zhang, X., Houzelot, V., Ferrari, F., Rodrigues, J., Pons, M. N., Bani, A., Echevarria, G., \& Morel, J. L. (2016). Agromining: Producing Ni salts from the biomass of hyperaccumulator plants. IMPC 2016 - 28th International Mineral Processing Congress, September 2016.

Simonnot, M.-O., Vaughan, J., \& Laubie, B. (2018). Processing of bio-ore to products. In: Van der Ent, A., Echevarria, G., Baker, A. J. M., and Morel, J. L. eds. Agromining: Farming for Metals, 39-51. Springer, Cham. https://doi. org/10.1007/978-3-319-61899-9_3.

Tang, Y. T., Deng, T. H. B., Wu, Q. H., Wang, S. Z., Qiu, R. L., Wei, Z. Bin, Guo, X. F., Wu, Q. T., Lei, M., Chen, T. Bin, Echevarria, G., Sterckeman, T., Simonnot, M. O., \& Morel, J. L. (2012). Designing cropping systems for metal-contaminated sites: A review. Pedosphere, 22(4), 470-488. https://doi.org/10.1016/S1002-0160(12)60032-0.

Van der Ent, A., Baker, A. J. M., Reeves, R. D., Chaney, R. L., Anderson, C. W. N., Meech, J. A., Erskine, P. D., Simonnot, M. O., Vaughan, J., Morel, J. L., Echevarria, G., Fogliani, B., Rongliang, Q., \& Mulligan, D. R. (2015). Agromining: Farming for metals in the future? Environmental Science and Technology, 49(8), 4773-4780. https://doi.org/10.1021/es506031u.

Van der Ent, A., Baker, A. J. M., van Balgooy, M. M. J., \& Tjoa, A. (2013). Ultramafic nickel laterites in Indonesia (Sulawesi, Halmahera): Mining, nickel hyperaccumulators and opportunities for phytomining. Journal of Geochemical Exploration, 128, 72-79. https://doi.org/10.1016/j.gexplo.2013.01.009.

Wang, L., Hou, D., Shen, Z., Zhu, J., Jia, X., Ok, Y. S., Tack, F. M. G., \& Rinklebe, J. (2020). Field trials of phytomining and phytoremediation: A critical review of influencing factors and effects of additives. Critical Reviews in Environmental Science and Technology, 50(24), 2724-2774. https://doi.org/10.1080/10643389.20 19.1705724.

Wiche, O., \& Heilmeier, H. (2016). Germanium (Ge) and rare earth element (REE) accumulation in selected energy crops cultivated on two different soils. Minerals Engineering, 92, 208-215. https://doi.org/10.1016/j.mineng.2016.03.023.

Wiche, O., Székely, B., Kummer, N. A., Moschner, C., \& Heilmeier, H. (2016). Effects of intercropping of oat (Avena sativa L.) with white lupin (Lupinus albus L.) on the mobility of target elements for phytoremediation and phytomining in soil solution. International Journal of Phytoremediation, 18(9), 900-907. https://doi.org/ 10.1080/15226514.2016.1156635.

Wiche, O., Tischler, D., Fauser, C., Lodemann, J., \& Heilmeier, H. (2017). Effects of citric acid and the siderophore desferrioxamine B (DFO-B) on the mobility of germanium and rare earth elements in soil and uptake in Phalaris arundinacea. International Journal of Phytoremediation, 19(8), 746-754. https://doi.org/10.1080/ 15226514.2017.1284752. 
Willscher, S., Mirgorodsky, D., Jablonski, L., Ollivier, D., Merten, D., Büchel, G., Wittig, J., \& Werner, P. (2013). Field scale phytoremediation experiments on a heavy metal and uranium contaminated site, and further utilization of the plant residues. Hydrometallurgy, 131-132, 46-53. https://doi.org/10.1016/j. hydromet.2012.08.012.

Wilson-Corral, V., Anderson, C. W. N., \& Rodriguez-Lopez, M. (2012). Gold phytomining. A review of the relevance of this technology to mineral extraction in the 21st century. Journal of Environmental Management, 111, 249-257. https://doi. org/10.1016/j.jenvman.2012.07.037.

Wilson-Corral, V., Anderson, C. W. N., Rodriguez-Lopez, M., Arenas-Vargas, M., \& Lopez-Perez, J. (2011). Phytoextraction of gold and copper from mine tailings with Helianthus annuus L. and Kalanchoe serrata L. Minerals Engineering, 24(13), 1488-1494. https://doi.org/10.1016/j.mineng.2011.07.014. 